\title{
Między godnością a zniewoleniem. Naukowa refleksja na temat dziecka w perspektywie historycznej w jubileuszu czterdziestolecia białostockiej szkoły historii wychowania
}

\begin{abstract}
Abstrakt
Artykuł przedstawia osiągnięcia Katedry Historii Wychowania Wydziału Nauk o Edukacji Uniwersytetu w Białymstoku w jubileuszu 40-lecia istnienia. Autor zaprezentował najważniejsze osiągnięcia zespołu białostockich historyków wychowania, kierowanych przez profesor Elwirę Kryńską. Szczególnym obszarem badawczym opisanym $\mathrm{w}$ artykule są zagadnienia godności i zniewolenia dziecka w perspektywie historycznej. Artykuł ma także na celu zaprezentowanie głównych założeń VIII Ogólnopolskiej Konferencji Naukowej Dziecko w historii - między godnościq a zniewoleniem, która została zaplanowana na 24-25 maja $2021 \mathrm{r}$.
\end{abstract}

Słowa kluczowe: dziecko w historii, godność, zniewolenie.

\section{Between Dignity and Enslavement. Scientific Reflections on the Child From an Historical Perspective on the Fortieth Anniversary of the Białystok School of Education History}

\begin{abstract}
The article presents the achievements of the Department of Education History of the Faculty of Education Sciences at the University of Białystok on its $40^{\text {th }}$ anniversary. The author presents the most important achievements of the team of Bialystok's educational historians led by Professor Elwira Krynska. A special research area, described in the article, is the issue of the dignity and enslavement of the child in the historical perspective. The article also aims to present the main assumptions of the VIII National Scientific Conference The Child in History - between dignity and enslavement, which is planned for 24-25 May, 2021.
\end{abstract}

Keywords: the child in history, dignity, enslavement.

\footnotetext{
* Uniwersytet w Białymstoku, Wydział Nauk o Edukacji.

Artykuł otrzymano: 15.05.2020; akceptacja: 16.05.2020.
} 
W 2020 r. Katedra/Zakład Historii Wychowania Wydziału Nauk o Edukacji Uniwersytetu w Białymstoku będzie obchodzić jubileusz 40-lecia swego istnienia. Zakład Historii Wychowania został utworzony dzięki staraniom profesora Franciszka Januszka 1 marca 1980 r. (X lat Uniwersytetu... 2008: 216). Zakład znajdował się wówczas w strukturze Wydziału Pedagogiki i Psychologii Filii Uniwersytetu Warszawskiego w Białymstoku1 ${ }^{1}$. Od chwili powstania Zakład systematycznie rozwijał się kadrowo i poszerzał obszar poszukiwań badawczych. Pierwsze naukowe dociekania, podejmowane przez pracowników tej jednostki, dotyczyły tajnego nauczania na Białostocczyźnie w czasie II wojny światowej, martyrologii nauczycielstwa, wykorzystania czasu wolnego przez dzieci i młodzież, zagadnień resocjalizacji oraz efektywności kształcenia wiejskich szkół gminnych. W 1988 r. nastąpiła zmiana nazwy i powstał Zakład Historii Wychowania i Myśli Pedagogicznej (X lat Uniwersytetu... 2008: 221).

Od 2002 r., tj. od momentu objęcia funkcji kierownika Zakładu Historii Wychowania przez profesor Elwirę Jolantę Kryńską, zamierzenia naukowe Zakładu mieszczą się w kręgu szeroko rozumianej historii wychowania i dotyczą dziejów myśli pedagogicznej, zwłaszcza XX w. oraz genezy i rozwoju instytucji oświatowych (Utrwalić chwilę... 2007: 84). Obejmują zagadnienia związane z: oświatą szkolną i pozaszkolną, szkolnictwem prywatnym, aktywnością nauczycieli oraz krystalizowaniem się społecznej świadomości i rozwoju kultury Polski niepodległej; niezłomną walką przeciwko degradacji umysłowej i kulturalnej młodego pokolenia Polaków oraz poniesionymi stratami osobowymi i materialnymi w latach II wojny światowej, a także przeciwstawianiem się ideologizacji życia społecznego w okresie budowy „państwa socjalistycznego” i „nowego człowieka”.

Warto nadmienić, iż profesor E. Kryńska, której jubileusz pracy naukowej pokrywa się z jubileuszem działalności Katedry, w swoich badaniach wzorowała się na wybitnym historyku wychowania profesorze Stanisławie Mauersbergu. To pod jego opieką doskonaliła swój warsztat pracy naukowej i pasję do poszukiwań badawczych w ramach historii wychowania. Pani Profesor wielokrotnie pełniła funkcje promotora i recenzenta rozpraw doktorskich, recenzowała też dorobki naukowe w procedurze habilitacyjnej oraz w postępowaniu o tytuł profesora. Wśród wypromowanych doktorów jest wielu pracowników naukowych Wydziału Nauk o Edukacji UwB, m.in. dr hab. Urszula Wróblewska, prof. UwB, dr Anna Józefowicz, dr Łukasz Kalisz, dr Agata Samsel, dr Agnieszka Suplicka.

Awanse naukowe pracowników Zakładu Historii Wychowania i dalszy rozwój jednostki nie byłyby możliwe bez samodzielności naukowej jej kierownika. Profesor Elwira Kryńska w dniu 18 kwietnia 2013 r. otrzymała tytuł naukowy profesora, co skutkowało podniesieniem rangi Zakładu i utworzeniem Katedry

\footnotetext{
1 Uniwersytet w Białymstoku został utworzony z Filii Uniwersytetu Warszawskiego w Białymstoku i jako samodzielna jednostka naukowa rozpoczął swoje funkcjonowanie $1.10 .1997 \mathrm{r}$. na mocy Ustawy z dnia 19.06.1997 r. o utworzeniu Uniwersytetu w Białymstoku (Dz.U. 1997).
} 
Historii Wychowania (Tempora... 2017: 44). Ostatnia zmiana struktury opisywanej jednostki nastąpiła jako pokłosie tzw. Ustawy 2.0 (Dz.U. 2018) w październiku 2019 r., gdy Wydział Pedagogiki i Psychologii Uniwersytetu w Białymstoku zmienił nazwę na Wydział Nauk o Edukacji. Jednocześnie nastąpiła zmiana struktury wewnętrznej Wydziału, wobec czego powstała Katedra Historii i Teorii Wychowania, w skład której weszły: Zakład Historii Wychowania oraz Zakład Teorii Wychowania i Antropologii Pedagogicznej. W Zakładzie Historii Wychowania kierowanym przez prof. zw. dr hab. E. Kryńską pracują również: dr hab. Urszula Wróblewska, prof. UwB, dr Joanna Dąbrowska, dr Łukasz Kalisz i dr Agnieszka Suplicka. Natomiast Zakład Teorii Wychowania i Antropologii Pedagogicznej kierowany przez prof. zw. dr. hab. Andreia Harbatskiego tworzą także: dr Lidia Dakowicz, dr Anna Józefowicz, mgr Magda Kusiuk i mgr Sylwia Romanowska.

W Katedrze Historii Wychowania przez 40-letni okres działalności zrealizowano wiele inicjatyw naukowych, takich jak: granty Ministerstwa Nauki i Szkolnictwa Wyższego, Narodowego Centrum Nauki, staże naukowe i projekty badawcze.

Wymiernym efektem realizowanych zainteresowań badawczych jest znaczna liczba publikacji naukowych (książek i artykułów) oraz konferencji zorganizowanych przez pracowników Katedry. Cyklem konferencji, które na trwałe wpisały się do polskiej pedagogiki i historii wychowania z uwagi na wysokie walory naukowe, znakomite grono prelegentów, jak też dobrą organizację, są konferencje pod hasłem Dziecko w historii... . Pierwsza debata odbyła się pod hasłem Dziecko - studium korczakowskie (2012 r.), następna była związana z jubileuszem 1050. Rocznicy Chrztu Polski i dotyczyła sytuacji dziecka w kulturze chrześcijańskiej (2016 r.), natomiast 100. rocznica odzyskania przez Polskę niepodległości została upamiętniona konferencją Dziecko $w$ historii - sytuacja dziecka w odrodzonym państwie polskim (2018 r.).

Akcentując wątek jubileuszowy, zamierzamy zaprosić do udziału w kolejnej VIII Ogólnopolskiej Konferencji Naukowej Dziecko w historii - między godnościq a zniewoleniem. Konferencja odbędzie się w siedzibie Wydziału Nauk o Edukacji Uniwersytetu w Białymstoku w dniach 24-25 maja 2021 r.

Godność i zniewolenie stanowią kwintesencję działań naukowych białostockiego zespołu historyków wychowania. W dorobku naukowym profesor E. Kryńskiej zniewolenie i godność jednostki to motywy kluczowe. Pani Profesor zajmowała się opracowaniem zagadnień poświęconych m.in. tajnemu nauczaniu w czasie okupacji hitlerowskiej, jak również indoktrynacji młodzieży w okresie komuni$\mathrm{zmu}^{2}$. Były to nowatorskie badania naukowe, zwieńczone publikacjami wydanymi w czasie, gdy pewne prawdy historyczne z uwagi na poprawność polityczną były przemilczane i niechętnie podejmowane przez naukowców.

\footnotetext{
2 Na szczególną uwagę zasługuje publikacja: Terror i konspiracja. Młodzież wobec indoktrynacji komunistycznej 1945-1956 (2004) jak też monografia współautorska - Kryńska E., Mauersberg S. (2003) - nagrodzona przez Wydział I Nauk Społecznych PAN, który na posiedzeniu plenarnym 21.11.2006 r. przyznał autorom nagrodę naukową w dziedzinie pedagogiki im. Władysława Spasowskiego.
} 
Zniewolenie odnosi się także do zbrodni systemów, które walczyły z godnością człowieka. Dzięki inicjatywie Katedry Historii Wychowania oraz Fundacji Pomocy Młodocianym Więźniom Politycznym z lat 1944-1956 „Jaworzniacy” na Uniwersytecie w Białymstoku powstała wystawa Zbrodnie w majestacie prawa 1954-1956 oraz dokumentujący ją dwujęzyczny - polsko-angielski - album (Pruszyński 2004). Oddzielnym zagadnieniem badawczym realizowanym przez białostocki zespół historyków wychowania jest patriotyzm rozumiany m.in. jako walka ze zniewoleniem narodu i troska o godność osobową człowieka. Szczególne cenna w tej materii jest obszerna - licząca 710 stron - publikacja wieloautorska Patriotyzm a wychowanie (Patriotyzm... 2009), czy też dwutomowe wydanie Kobieta a patriotyzm... (Kobieta... 2012a; 2012b) oraz monografia Skazane za patriotyzm... (Kryńska 2012b).

Zespół historii wychowania podejmuje także inicjatywy promujące godność człowieka i prowadzi liczne badania naukowe na temat historii instytucji dobroczynnych (Kryńska 2012a; Kalisz 2017; Dąbrowska 2009), kształcenia i wychowania mniejszości religijnych i narodowościowych (Wróblewska 2015) oraz promuję pedagogikę opartą na wartościach (Wychowanie... 2007; Kalisz 2013). W 2015 r. Katedra Historii Wychowania wraz z działającym przy niej Akademickim Kołem Katolickiego Stowarzyszenia Młodzieży (ksm.uwb.edu.pl) była współorganizatorem IV Dni Godności Życia, w ramach których zorganizowano Ogólnopolską Konferencję Naukową Otoczmy Troską Życie (dnigodnoscizycia.pl).

Prezentowany dorobek jest tylko częścią bogatego dziedzictwa historyków wychowania z Białegostoku, oddzielnymi kwestiami są badania regionalne (Kryńska, Suplicka, Wróblewska 2018; Suplicka 2015; Kalisz 2013; Dąbrowska 2015), biograficzne (Dąbrowska 2008), terenowe i przeprowadzane międzynarodowe kwerendy zagraniczne, działalność popularyzatorska, organizacja wystaw czy wyróżnienia i nagrody przyznawane pracownikom Katedry. Niewątpliwie działalność naukowa, organizacyjna i dydaktyczna zespołu kierowanego przez profesor E. Kryńską przyczyniła się do rozwoju historii wychowania jako subdyscypliny pedagogiki i może być nazwana mianem białostockiej szkoły historii wychowania.

Tym bardziej zachęcam czytelników niniejszego artykułu do udziału w jubileuszowej konferencji Dziecko w historii - między godnościq a zniewoleniem objętej patronatem honorowym Marszałka Województwa Podlaskiego, Rektora Uniwersytetu w Białymstoku, Komitetu Nauk Pedagogicznych Polskiej Akademii Nauk i Towarzystwa Historii Edukacji.

Wśród członków Rady Naukowej Konferencji znaleźli się przedstawiciele wielu ośrodków naukowych, m.in.: prof. zw. dr hab. Kalina Bartnicka, prof. zw. dr hab. Krzysztof Jakubiak, prof. zw. dr hab. Wiesław Jamrożek, prof. zw. dr hab. Janina Kostkiewicz, prof. zw. dr hab. Piotr Niczyporuk, prof. zw. dr hab. Jerzy Nikitorowicz, prof. zw. dr hab. Hanna Markiewiczowa, prof. zw. dr hab. Karol Poznański, prof. zw. dr hab. Władysława Szulakiewicz, ks. prof. zw. dr hab. Edward Walewander, prof. zw. dr hab. Krystyna Wróbel-Lipowa, dr hab. Stanisław Bożyk, prof. UwB, dr hab. Witold Chmielewski, prof. AIK, ks. dr hab. Czesław Galek, prof. WSZA, 
dr hab. Janina Kamińska, prof. UW. Natomiast Interdyscyplinarny Komitet Naukowy Konferencji pod kierownictwem prof. zw. dr hab. Elwiry Kryńskiej tworzą profesorowie reprezentujący takie dziedziny, jak: pedagogika, socjologia, teologia i prawo.

Zamierzeniem organizatorów jest dysputa akademicka poświęcona godności osobowej, osobowościowej i osobistej dziecka w sytuacji zniewolenia, utraty wolności i całkowitej zależności od innych. Może to być zniewolenie dotyczące różnych sfer życia ludzkiego, na przykład fizyczne ograniczenie, tzn. uzależnienie czyjegoś zdrowia i życia od woli drugiego człowieka, czy też zniewolenie umysłu prowadzące do zatarcia własnej osobowości, godności na skutek różnorodnych czynników, w tym - jak twierdził Karl Jaspers - „rozbicia człowieka na dwie osoby” pod wpływem olbrzymiej presji ideologicznej. Powoduje to, że dzieciństwo jako zjawisko dotyczące każdego człowieka bywa nadal zawłaszczane i zniewalane w najróżniejszy sposób, tym samym zatracając swój niepowtarzalny, indywidualny, podmiotowy charakter, mimo że humanistyczne ujęcie egzystencji ludzkiej staje się dziś szczególnie ważne i - może - najbardziej ludziom potrzebne.

Dlatego głównym celem konferencji Dziecko $w$ historii - między godnościq a zniewoleniem jest próba odpowiedzi na pytania: Jakie były i są źródła praw człowieka? Czy godność jednostki była i jest nadal wartością? Jakie w przeszłości były i są współcześnie przyczyny zniewolenia jednostki? Dlaczego dochodzi do ograniczania wolności człowieka i tłamszenia jego godności?

Odpowiedzi na sformułowane pytania są o tyle ważne, że godność człowieka w naszej kulturze stanowi fundament przyjmowanej powszechnie koncepcji człowieka. Tymczasem we współczesnym świecie, zdeterminowanym głównie przez czynniki polityczne i gospodarcze oparte na modelu neoliberalnego kapitalizmu, następuje pogłębianie różnic społeczno-ekonomicznych prowadzących do poszerzania przestrzeni i grup wykluczenia oraz relatywizacji i dewaluacji samej idei poszanowania godności ludzkiej.

Lista zagadnień, które mogą stać się przedmiotem obrad, jest długa i ciągle otwarta. Nie chcąc jej zamykać w ciasnych ramach subdyscyplin pedagogicznych, starając się o to, aby przekaz miał wymiar interdyscyplinarny, wieloaspektowy, wyrażony również artystycznie, proponujemy, aby referaty i dyskusje koncentrowały się wokół następujących obszarów tematycznych:

- Godność i zniewolenie - próba definicji,

- Godność jako źródło i fundament wszelkich praw i wolności jednostki,

- Filozoficzne konteksty interpretacji godności ludzkiej,

- Źródła praw człowieka w kontekście historycznym,

- Prawa dziecka w myśli pedagogicznej,

- Prawa dziecka w aspekcie prawnym,

- Przyczyny i warunki zniewolenia dziecka,

- „Obrona” dziecka przed ideologiczną organizacją życia społeczno-politycznego,

- Zniewolenie jednostki w systemach totalitarnych XX w., 
- Dziecko w środowisku rodzinnym zróżnicowanym społecznie, etnicznie, ekonomicznie,

- Dziecko w kręgu potrzeb i oczekiwań społecznych,

- Dziecko w zinstytucjonalizowanych formach kształcenia i wychowania,

- Dziecko jako bezpośredni adresat pomocy i form opieki dobroczynnej.

Podana tematyka ma charakter orientacyjny i w niczym nie uszczupla inwencji i pomysłowości uczestników obrad, którzy mogą wysunąć własne propozycje, mieszczące się w ogólnej koncepcji konferencji.

Wszelkie informacje dotyczące konferencji, jak również Katedry Historii i Teorii Wychowania znajdują się na stronie: http://dzieckowhistorii.uwb.edu.pl/

\section{Bibliografia}

X lat Uniwersytetu w Białymstoku 1997-2007 (2008), J. Nikitorowicz, E. Kryńska i in. (red.), Białystok, Wydawnictwo Uniwersytetu w Białymstoku.

Dąbrowska J. (2008) Klementyna: rzecz o Klementynie z Tańskich Hoffmanowej, Białystok, Wydawnictwo Uniwersyteckie Trans Humana.

Dąbrowska J. (2009) Związek Dobroczynności Patriotycznej Warszawianek - pierwsza na ziemiach polskich organizacja kobieca w: Patriotyzm a wychowanie, E. Kryńska, J. Dąbrowska, A. Szarkowska, U. Wróblewska (red.), Białystok, Wydawnictwo Uniwersyteckie Trans Humana, s. 107-116.

Dąbrowska J. (2015) Uniwersytet w Białymstoku in statu nascendi (1968-1997). Przegląd źródet, Białystok, Wydawnictwo Uniwersyteckie Trans Humana.

Kalisz Ł. (2013) 20-lecie Studium Teologii w Białymstoku, Białystok, Wydawnictwo Uniwersyteckie Trans Humana.

Kalisz Ł. (2017) Salezjanie i ich opieka nad dzieckiem w Supraślu (1936-1950) w: Dziecko $w$ historii - $w$ kręgu kultury chrześcijańskiej, E. Kryńska, A. Suplicka, U. Wróblewska (red.), Białystok, Wydawnictwo Uniwersytetu w Białymstoku, s. $454-463$.

Kobieta a patriotyzm. Konteksty historyczno-pedagogiczne XVI-XX wieku (2012a), E. Kryńska, Ł. Kalisz, A. Konopacki (red.), Białystok, Wydawnictwo Uniwersyteckie Trans Humana.

Kobieta a patriotyzm. Konteksty historyczno-pedagogiczne XX-XXI wieku (2012b), E. Kryńska, A. Szarkowska, U. Wróblewska (red.), Białystok, Wydawnictwo Uniwersyteckie Trans Humana. 
Kryńska E. (2012a) Polski Biały Krzyż (1918-1961), Białystok, Wydawnictwo Uniwersyteckie Trans Humana.

Kryńska E. (2012b) Skazane za patriotyzm. „Druga konspiracja” na Białostocczyźnie 1945-1956, Białystok, Wydawnictwo Uniwersyteckie Trans Humana.

Kryńska E., Mauersberg S. (2003) Indoktrynacja młodzieży szkolnej w Polsce w latach 1945-1956, Białystok, Wydawnictwo Uniwersyteckie Trans Humana.

Kryńska E., Suplicka A., Wróblewska U. (2018) Dzieje oświaty w regionie - województwo białostockie (1919-1939), Warszawa, Oficyna Wydawnicza ASPRA-JR.

Patriotyzm a wychowanie (2009), E. Kryńska, J. Dąbrowska, A. Szarkowska, U. Wróblewska (red.), Białystok, Wydawnictwo Uniwersyteckie Trans Humana.

Pruszyński J. (2004) Katalog wystawy „Zbrodnie w majestacie prawa 1944-1956”, Warszawa, Fundacja Pomocy Młodocianym Więźniom Politycznym lat 1944-1956 „Jaworzniacy".

Suplicka A. (2015) Prywatne szkoły średnie ogólnokształcąe i zawodowe w województwie białostockim w II Rzeczypospolitej, Białystok, Wydawnictwo Uniwersytetu w Białymstoku.

Tempora mutandur et nos mutamur in illis... XL lat Wydziału Pedagogiki i Psychologii Uniwersytetu w Białymstoku. Dekada 2008-2017 (2017), M. Sobecki, A. Korzeniecka-Bondar (red.), Białystok, Wydawnictwo Uniwersytetu w Białymstoku.

Terror i konspiracja. Młodzież wobec indoktrynacji komunistycznej 1945-1956 (2004), E. Kryńska (red.), Białystok, Wydawnictwo Uniwersyteckie Trans Humana.

Ustawa z dnia 19 czerwca 1997 r. o utworzeniu Uniwersytetu w Białymstoku, Dz.U. 1997, nr 102, poz. 642.

Ustawa z dnia 20 lipca 2018 r. - Prawo o szkolnictwie wyższym i nauce, Dz.U. 2018, poz. 1668.

Utrwalić chwilę. XXX-lecie Wydziału Pedagogiki i Psychologii Uniwersytetu w Białymstoku 1977-2007 (2007), E. Kryńska (red.), Białystok, Wydawnictwo Uniwersyteckie Trans Humana.

Wróblewska U. (2015) Działalność kulturalno-oświatowa Karaimów w Drugiej Rzeczypospolitej, Białystok, Wydawnictwo Uniwersyteckie Trans Humana.

Wychowanie - ale jakie? (2007), E. Kryńska, A. Skreczko (red.), Białystok, Wydawnictwo Uniwersyteckie Trans Humana. 


\section{Źródła internetowe}

http://dzieckowhistorii.uwb.edu.pl/ [dostęp: 11.05.2020].

http://ksm.uwb.edu.pl/ [dostęp: 11.05.2020].

http://www.dnigodnoscizycia.pl [dostęp: 11.05.2020]. 